\title{
THICKNESS AND GEODETIC MASS BALANCE CHANGES FOR THE TRIGLAV GLACIER (SOUTHEASTERN ALPS) FROM 1952 TO 2016
}

Mihaela Triglav Čekada, Matija Zorn

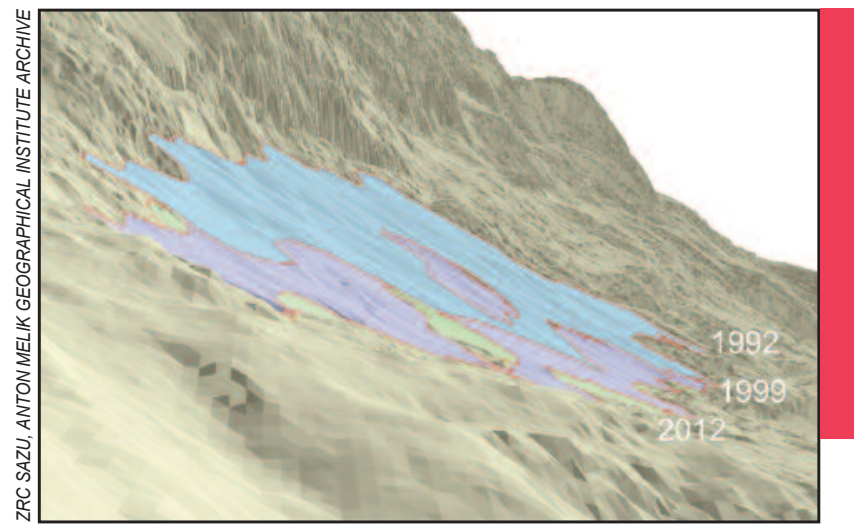

Side view of the extent of the Triglav Glacier in 1992, 1999, and 2012, covering approximately 1 hectare. 
DOI: https://doi.org/10.3986/AGS.7673

UDC: $911.2: 551.324 .3(234.323 .6) » 1952 / 2016 \ll$

COBISS: 1.01

Mihaela Triglav Čekada ${ }^{1}$, Matija Zorn ${ }^{2}$

\title{
Thickness and geodetic mass balance changes for the Triglav Glacier (southeastern Alps) from 1952 to 2016
}

\begin{abstract}
Various geodetic and lidar measurements performed on the Triglav Glacier (Julian Alps, Slovenia) make it possible to study not only the extent of the glacier but also changes in its thickness and volume. These measurements also make it possible to calculate the geodetic mass balance of the glacier. Thickness and volume changes were calculated using glacier area measurements from 1952, 1975, and 1992, and annually between 1999 and 2016. The mean thickness decreased from $39.2 \mathrm{~m}$ in 1952 to $2.45 \mathrm{~m}$ in 2012. The maximum thickness decreased from $48.3 \mathrm{~m}$ in 1952 to $5.2 \mathrm{~m}$ in 2007 . The mean specific mass balance was calculated for the area of 1 hectare that the glacier covered in 2016. From 1952 to 2016, the annual specific mass balance was $-0.45 \mathrm{~m}$ w.e. $\mathrm{a}^{-1}$.
\end{abstract}

KEY WORDS: climate change, glacier thickness, glacier volume, geodetic mass balance, Triglav Glacier, Slovenia

\section{Spremembe debeline in geodetske masne bilance Triglavskega ledenika (jugovzhodne Alpe) v obdobju 1952-2016}

POVZETEK: Različne geodetske in lidarske izmere velikosti Triglavskega ledenika omogočajo, poleg preučevanja sprememb njegove površine, tudi preučevanje sprememb debeline in prostornine. Poznavanje teh sprememb omogoča tudi izračun geodetske masne bilance ledenika. Za ugotavljanje sprememb debeline in prostornine, smo uporabili meritve površine ledenika v letih 1952, 1975, 1992 ter meritve med letoma 1999 in 2016. Povprečna debelina ledenika se je zmanjšala iz 39,2 m leta 1952 na 2,45 m leta 2012. Največja debelina pa se je zmanjšala iz 48,3 m leta 1952 na 5,2 m leta 2007. Letno specifično masno bilanco smo ugotavljali za območje velikosti 1,0 ha, ki ga je ledenik pokrival leta 2016. Povprečna specifična masna bilanca v celotnem obdobju 1952-2016 je bila $-0,45$ m w.e. $\mathrm{a}^{-1}$ (metri vodnega ekvivalenta na leto).

KLJUČNE BESEDE: podnebne spremembe, debelina ledenika, prostornina ledenika, geodetska masna bilanca, Triglavski ledenik, Slovenija

This article was submitted for publication on November $2^{\text {nd }}, 2019$.

Uredništvo je prejelo prispevek 2. novembra 2019.

\footnotetext{
${ }^{1}$ Geodetic Institute of Slovenia and Faculty of Civil and Geodetic Engineering, University of Ljubljana, Ljubljana, Slovenia mihaela.triglav@gis.si (https://orcid.org/0000-0002-4200-2616)

${ }^{2}$ Research Centre of the Slovenian Academy of Sciences and Arts, Anton Melik Geographical Institute, Ljubljana, Slovenia

matija.zorn@zrc-sazu.si (https://orcid.org/0000-0002-5788-018X)
} 


\section{Introduction}

Glacier area and volume changes are among the more visible consequences of climate change (Zängl and Hamberger 2004). Due to climate change, glaciers are disappearing worldwide (Zemp et al. 2015; Slater et al. 2020). In this regard, very small glaciers, or glacierets (Kumar 2011), such as the Triglav Glacier (Gabrovec et al. 2013, 2014), are especially threatened. Although small, these glaciers are still an important indicator of climate change (Lipar et al. 2021) because they respond to it more rapidly than larger glaciers (Brown, Harper, and Humphrey 2010; Colucci and Guglielmin 2015; Hughes 2018). In addition, small glaciers represent a numerically significant group, accounting for up to $80 \%$ of all glaciers located in mid- to low-latitude mountain ranges (Huss and Fischer 2016).

Changes in the area of the Triglav Glacier have been studied with direct measurements since 1946 (see Gabrovec et al. 2013, 2014 and references therein) and based on historical photographs and maps since 1829 (e.g., Triglav Čekada and Gabrovec 2013; Triglav Čekada, Zorn, and Colucci 2014; Triglav Čekada 2018). During the period studied, the glacier area decreased significantly (Figure 1), as did its thickness. Compared to area changes, which were studied in detail in the past (see Gabrovec et al. 2014), much less is known about thickness and volume changes. Based on geodetic measurements of the glacier in 1952 and 1999 and in 1952 and 2001, Gabrovec (2002a, 2002b) calculated the thickness and volume change. Verbič and Gabrovec (2002) calculated the volume of the Triglav Glacier based on ground-penetrating radar survey (GPRS) thickness measurements in 2000. Gabrovec (2008) later calculated the volumes of the Triglav Glacier for 1937, 1952, 1975, 1992, 1999, and 2005 based on photogrammetrically derived areas. Triglav Čekada and Gabrovec (2013) calculated the volumes of the glacier from 1976 to 2011 based on area measurements derived from non-metric photography, as well as using an empirical equation. The thickness of the glacier was also measured with GPRS in 2013. The GPRS thickness measurements were conducted at the same measuring points as in 2000 (Del Gobbo et al. 2016).

This article presents new calculations of thickness and volume changes as well as the first estimates of geodetic mass balance changes of the Triglav Glacier from 1952 to 2016. The calculations are based on digital terrain models (DTMs) developed based on geodetic tachymetric and photogrammetric area measurements of the glacier.

\section{Data and methods}

\subsection{Geodetic, photogrammetric, and lidar measurements}

Geodetic measurements on the Triglav Glacier have been performed regularly since 1999 (Triglav Čekada and Gabrovec 2008; Gabrovec et al. 2013, 2014), but the first tachymetric measurement was already made in 1952. Geodetic measurements made it possible to develop the DTMs that were used for thickness and volume calculations (Section 2.2.). The DTMs were derived from tachymetric or photogrammetrically acquired contour lines, and individual points on the surface of the glacier and glacier's perimeter.

Photogrammetric measurements were carried out with a calibrated medium-format Rolleimetric 6006 photogrammetric camera. Stereo photogrammetric measurements were conducted based on measured reference points by tachymetry and terrestrial or aerial photogrammetrically derived images. The results are presented on a map with a scale of 1:1,000 and a $5 \mathrm{~m}$ contour interval. The points on the surface of the glacier were measured at a density that depended on the annual area of the glacier, mostly at points where the terrain varied significantly, and so their number varies from year to year. The horizontal accuracy of these maps can be analytically estimated to be better than $20 \mathrm{~cm}$ (Triglav Čekada, Crosilla and Kosmatin Fras 2010), and vertical accuracy to be better than $0.5 \mathrm{~m}$ (taking into account, for example, the accuracy of control points used).

In addition to the detailed measurements of the glacier's area, the broader area around the glacier was measured three times between 1999 and 2016. In 2005, a special aerial stereo photogrammetric survey was performed with a large-format Leica RC 30 camera (Gabrovec et al. 2014) with an imaging scale of 1:4,000. A stereophotogrammetric acquisition of the area covering the approximate extent of the glacier in 1952 was performed. The results were mapped at a scale of 1:1,000. 
In 2012 two aerial laser scanning surveys (lidar) were performed. The first lidar survey of the broader area around the Triglav Glacier was performed at the end of the accumulation period, on May 18th, 2012, and the second almost at the end of the ablation period, on September 18th, 2012 (Triglav Cekada et al. 2013). The latter was used in this study because it represents the local minimum of the glacier's area and depth. In both cases, a Riegl LM5600 laser scanner was used with a wavelength of $1550 \mathrm{~nm}$, an average density of all points at 8 points $/ \mathrm{m}^{2}$, and an average flying height $700 \mathrm{~m}$ above the ground. Within the framework of the national aerial laser scanning of Slovenia, the broader area was again surveyed by lidar on August 8th, 2014 with a Riegl LMS-Q780 laser scanner with a wavelength of $1064 \mathrm{~nm}$, an average density of 5 points $/ \mathrm{m}^{2}$, and a flying height $1000 \mathrm{~m}$ above the ground. The analytically determined vertical accuracy of all three lidar surveys is better than $30 \mathrm{~cm}$, derived from equipment specifications and applied flying height above the ground (Triglav Čekada, Crosilla and Kosmatin Fras 2009). In 2014, a tachymetric survey of the glacier was also performed, and it was used to calculate the volume differences for 2014 (Figure 4) because lidar shows the glacier still very much under the snow. In all three lidar cases, a DTM with a cell size of $1 \times 1 \mathrm{~m}$ was created from the laser point clouds.

The glacier measurements for 1975 and 1992 were based on stereo photogrammetric acquisition from the large-format Cyclical Aerial Surveying of Slovenia (CAS) aerial photographs. The results were mapped at a scale of 1:5,000, and the contour interval is $5 \mathrm{~m}$. For 1992, a DTM with a cell size of $10 \times 10 \mathrm{~m}$ was also created. CAS aerial photographs for 1975 were oriented in the D48/GK national coordinate system based on five identical reference points, which were clearly visible on the stereo images of special aerial photography from 2005. CAS aerial photographs for 1992 were oriented based on nine reference points from the 2005 stereo images. Due to the shadow cast by the peak of Mount Triglav on the central part of a snow-covered area of the glacier, the orientation and stereo acquisition of data from the 1975 imagery was more challenging. Thus, the resulting lower contrast inside the shadow area may have resulted in higher vertical errors.

The area of the glacier was geodetically measured on September $8^{\text {th }}, 2013$, two weeks before the GPRS survey (September $22^{\text {nd }}-24^{\text {th }}, 2013$; Del Gobbo et al. 2016). The 2013 DTM was created using both measurements: the glacier perimeter and points on the glacier's surface from the first measurement, and additional geodetic points from the glacier surface from the second one.

The measuring techniques used in the study years for area measurements are shown in Table 1. For 1975 and 2001, no areas are given because in these years the glacier was completely snow-covered. In these years the CAS photos were made in mid- and late October and the glacier was already covered with snow

Table 1: Measuring techniques applied for the Triglav Glacier area measurements ( ${ }^{*}$ snow-covered glacier).

\begin{tabular}{lllcc}
\hline Year & Survey/source date & Measuring techniques & Scale & Glacier area (hectares) \\
\hline 1952 & October 4 & Tachymetry & $1: 2,500$ & 14.0 \\
1975 & October 29 & Cyclical Aerial Surveying of Slovenia & $1: 5,000$ & ${ }^{*}-$ \\
1992 & September 8 & Cyclical Aerial Surveying of Slovenia & $1: 5,000$ & 4.3 \\
1999 & September 13-15 & Medium-format aerial photogrammetric survey and tachymetry & $1: 1,000$ & $1.1^{*}$ \\
2001 & October 16-17 & Medium-format aerial photogrammetric survey and tachymetry & $1: 1,000$ & ${ }^{*}-$ \\
2003 & August 26-27 & Medium-format aerial photogrammetric survey and tachymetry & $1: 1,000$ & 0.6 \\
2005 & August 24-25 & Special large-format aerial photogrammetric survey & $1: 1,000$ & $1.2^{*}$ \\
2007 & September 13 & Tachymetry and medium-format terrestrial photogrammetric survey & $1: 1,000$ & 0.6 \\
2008 & August 27-28 & Tachymetry and medium-format terrestrial photogrammetric survey & $1: 1,000$ & $1.1^{*}$ \\
2009 & September 22-23 & Tachymetry and medium-format terrestrial photogrammetric survey & $1: 1,000$ & 0.6 \\
2010 & September 14-15 & Tachymetry and medium-format terrestrial photogrammetric survey & $1: 1,000$ & $2.5^{*}$ \\
2011 & September 13-14 & Tachymetry and medium-format terrestrial photogrammetric survey & $1: 1,000$ & $2.4^{*}$ \\
2012 & September 18 & Special aerial laser scanning (lidar) & & 0.6 \\
2013 & September 8 & Tachymetry and medium-format terrestrial photogrammetric survey & $1: 1,000$ & $2.5^{*}$ \\
2014 & August 25 & Tachymetry and medium-format terrestrial photogrammetric survey & $1: 1,000$ & 3.6 \\
2015 & September 9-10 & Tachymetry and medium-format terrestrial photogrammetric survey & $1: 1,000$ & $1.7^{*}$ \\
2016 & September 24 & Tachymetry and medium-format terrestrial photogrammetric survey & $1: 1,000$ & $1.0^{*}$ \\
\hline
\end{tabular}


Acta geographica Slovenica, 60-2, 2020

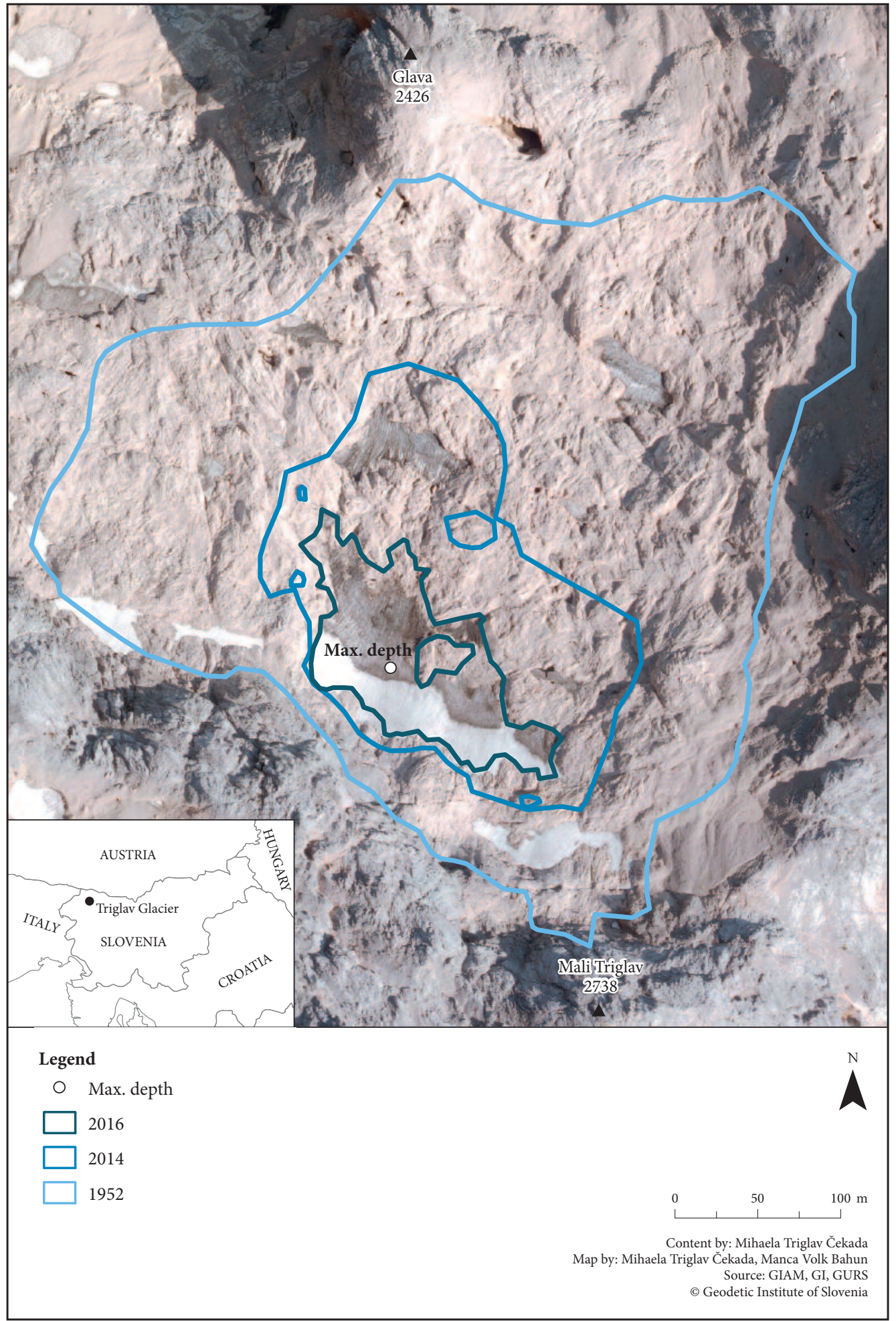


(less than a meter thick) of a new accumulation season (Gabrovec et al. 2014), which has to be taken into account when interpreting the results. For the 1992 CAS photos, only the area of exposed ice is given, not including surrounding snow fields. Between 1999 and 2016, the area studied was mostly snow-covered. The glacier's actual snow-free area was only measured in 2003, 2007, 2009, and 2012.

Using area measurements, DTMs for all the study years were created and used for further thickness and volume calculations.

\subsection{Thickness and volume}

The relative thickness of the glacier, which is the vertical height difference between two years studied (Figure 2; Table 2), was calculated as the height difference between the two cells at the same location in the two DTMs applied (Figures 3, 4, and 6). During the glacier area measurements, glacier ice was not always exposed because at the end of the ablation period it was still covered with firn or snow (Table 1). For these years the calculated thickness and volume refer to the entire (i.e., combined) thickness of ice, firn, and snow, and not only the thickness of the ice.

The mean relative thickness of the glacier was calculated as the change in relative thickness in an area for which the volume change was studied; that is, for 14 hectares that the glacier covered in 1952 and for 1 hectare that the glacier covered in 2016. Because 2012 represents the glacier minimum in the period studied, sometimes (e.g., Table 3) the changes in relative thickness refer to the thickness change between the year studied and 2012 .

The mean absolute thickness of the glacier (i.e., the mean difference between the surface of the glacier and the bedrock) was obtained taking into the account the mean relative thickness along with the GPRS measurements from 2013 (Del Gobbo et al. 2016). The 2013 GPRS measurements showed an ice layer averaging $1.95 \mathrm{~m}$ thick and a firn layer averaging $3 \mathrm{~m}$ thick (a total of $4.95 \mathrm{~m}$ ).

To obtain the mean absolute thickness for 2012 as the glacier minimum in the period studied, $2.5 \mathrm{~m}$ (a mean relative thickness between 2013 and 2012) was subtracted from the 2013 GPRS-measured mean absolute thickness of $4.95 \mathrm{~m}$ (Del Gobbo et al. 2016) to obtain $2.45 \mathrm{~m}$ as the mean absolute thickness for 2012 (Figure 5).

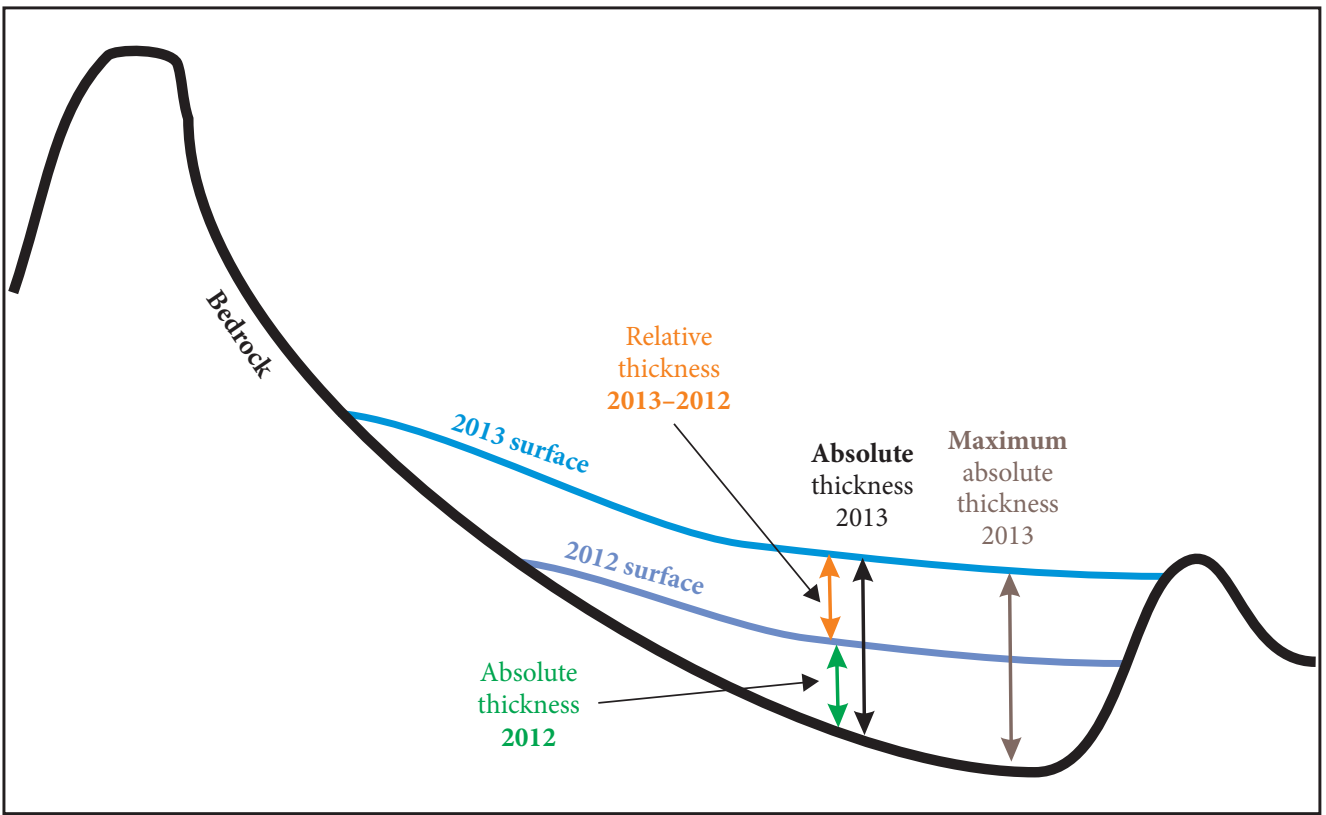

Figure 2: Sketch of relative and absolute thicknesses. The calculations refer to vertical thickness. 
The maximum absolute thickness of the glacier was obtained for the location (cell) where the GPRS measurements in 2013 gave the maximum thickness of the glacier (Figure 1). For this cell, first the relative thickness between the year studied and 2013 was calculated. If the glacier was thicker in the year studied, then a layer of ice $5 \mathrm{~m}$ thick and layer of firn $3 \mathrm{~m}$ thick ( $8 \mathrm{~m}$ in total) from 2013 GPRS measurements (Del Gobbo et al. 2016) were added to the relative thickness, resulting in the maximum absolute thickness. If, in the year studied, the glacier was thinner than in 2013, the mean relative thickness was subtracted from the GPRS measurements from 2013 to obtain the maximum absolute thickness (Figure 5).

The volumetric changes of the glacier for 1952, 1975, 1992, 2001, 2005, 2012, and 2014 were calculated for an area of 14 hectares covered by the glacier in 1952 (Figure 3). Because the area of the glacier from 1999 to 2016 varied between 2.5 and 1 hectares, the volumetric changes in this period were also calculated for the area of 1 hectare that the glacier covered in 2016 (Figures 1 and 6). To allow better comparison through the entire period studied, the 1-hectare area from 2016 was also used for the volumetric change calculations for 1952, 1975, and 1992 (Tables 3 and 4).

The volumes were calculated using ArcGIS software, which allows calculation of volumes by producing a closed TIN (triangulated irregular network) by combining contour lines and individual points on the surface of the glacier and perimeter of the glacier. The TIN was then interpolated to a DTM raster with a grid size of $5 \times 5 \mathrm{~m}$.

\subsection{Geodetic mass balance}

Mass balance was introduced to compare changes in the mass of different glaciers. It describes the decrease or increase in the glacier's mass in the period studied. The mass balance is a product of volume change and the density of material in that volume. The mass balance can be measured directly (e.g., the glaciological mass balance) or indirectly (e.g., the geodetic mass balance, measured by geodetic methods; Tihbert et al. 2008; Zemp et al. 2010; Fischer 2011). Thus the geodetic mass balance can be calculated for all glaciers on which volumetric changes can be calculated and for which information is available on the density of snow, firn, and ice that has melted or newly accumulated (Fischer 2011; Huss 2013).

The mass balance measured for a specific location on the glacier is known as a specific mass balance and is described by the meters of water equivalent [ $\mathrm{m}$ w.e.], or for the annual (net) specific mass balance in meters of water equivalent per year [m w.e. $\mathrm{a}^{-1}$ ] (Benn and Evans 2010; Fischer 2011).

In the case of the Triglav Glacier, one glacial year was used as the base unit because geodetic measurements were mainly conducted at the end of the ablation period. For calculating the mass balance, an area of 1 hectare was used, which the glacier covered in 2016.

The use of adequate snow and ice densities is essential when calculating the mass balance. For example, newly fallen snow has a density between 50 and $200 \mathrm{~kg} / \mathrm{m}^{3}$, firn (snow that has survived at least one ablation period) between 400 and $830 \mathrm{~kg} / \mathrm{m}^{3}$, and glacial ice 830 to $917 \mathrm{~kg} / \mathrm{m}^{3}$ (Benn and Evans 2010). However, in geodetic mass balance calculation, a uniform density for the entire volume change is often applied. For larger alpine-type glaciers, an average value of $850 \mathrm{~kg} / \mathrm{m}^{3}$ is often used (Zemp et al. 2010; Fischer 2011). Thibert et al. (2008) give a density of $600 \mathrm{~kg} / \mathrm{m}^{3}$ for firn measured in the summer and autumn months. According to another source, this density is characteristic for firn at a depth of about $15 \mathrm{~m}$, whereas it is $500 \mathrm{~kg} / \mathrm{m}^{3}$ at a depth of about $5 \mathrm{~m}$ (Schwerzmann et al. 2006). Huss (2013) gives two values, $600 \mathrm{~kg} / \mathrm{m}^{3}$ and $700 \mathrm{~kg} / \mathrm{m}^{3}$, for firn in the Alps for average depths up to $10 \mathrm{~m}$.

On the Triglav Glacier, different layer densities were measured during the 2013 GPRS survey. A crosssection $1.75 \mathrm{~m}$ deep was dug into the firn. The first $20 \mathrm{~cm}$ represented a layer of new snow, which was deposited in early September, shortly before the measurements were conducted, and it had a density of $375 \mathrm{~kg} / \mathrm{m}^{3}$, whereas a density of $600 \mathrm{~kg} / \mathrm{m}^{3}$ was measured from $30 \mathrm{~cm}$ to the bottom of the cross-section (Del Gobbo et al. 2016).

In our calculations we used a uniform density of $600 \mathrm{~kg} / \mathrm{m}^{3}$ for the whole period studied (Section 3.2). In the period 1952 to 1999 most of the lost thickness was due to the loss of glacier ice and in the period after 1999 most of the lost thickness was due to the loss firn and snow. In Figure 8 a comparison of mass balance is given for the period 1952 to 1999 taking into account a density of $860 \mathrm{~kg} / \mathrm{m}^{3}$ (e.g., Zemp et al. 2010, 2015; Shahgedanova et al. 2012; Fischer, Huss, and Hoelzle 2015; Huss, Dhulst and Bauder 2015) and a density of $600 \mathrm{~kg} / \mathrm{m}^{3}$. 


\section{Results and discussion}

\subsection{Thickness and volume}

For the years for which the broader area of the Triglav Glacier was surveyed (1952, 1975, 1992, 2001, 2005, 2012, and 2014; i.e., 14 hectares that the glacier covered in 1952), the raster of relative thicknesses was calculated between the DTM for a selected year and the September 2012 DTM because the latter represents one of the glaciers' minimums in the period studied.

Figure 3 shows some reddish parts, which is the result of orientation errors contained in the DTMs from 1952, 1975, and 2001. These three years were transformed or oriented into the national coordinate system using a smaller number of reference points, all of which were inside the 14-hectare area; they were specifically located only around the narrow area representing the current glacier and Mount Glava. This results in the reddish parts mainly appearing in the east in the 1952 raster, in the east and west in 1975, and mainly in the west in 2001. In comparison, the model from 1992 is much better oriented because its orientation is based on nine points and not only five, as in the case of 1975 . For these years, the vertical accuracy is mostly $\pm 2 \mathrm{~m}$ or better, but poorer vertical accuracy may be expected for 1975 due to the problems with stereo photogrammetric acquisition mentioned in Section 2.1 (more details are provided in Gabrovec 2008 and Gabrovec et al. 2009). Gabrovec (2008) argues that due to this the volume for 1975 is most probably underestimated.

In Figure 3, relative thickness up to $2 \mathrm{~m}$ is shown in white and light gray. Especially for the DTMs for 1952,1975 , and 1992, it must be taken into account that this may be in the domain of vertical errors. The relative thicknesses up to $10 \mathrm{~m}$ are shown in yellowish-green shades, and higher relative thicknesses are in shades of blue.

The 2001 and 2014 calculations show almost the same amount of snow and firn because in these glacial years the weather conditions were favorable (e.g., Vrhovec and Velkavrh 2001) for glacier preservation and the glacier ice remained hidden under the firn through the entire ablation period. The highest relative thicknesses can be found along Mount Triglav's rock wall (the southern side on the images in Figure 3); that is, in the area where the glacier has persisted for the last two decades. Similar relative thicknesses as in 2001 and 2014 can also be seen in Figure 4, where the relative thicknesses between the end of the accumulation period and the end of the ablation period in 2012 are presented (May-September). The snow accumulates in certain karst depression regardless of the year observed as a result of favorable microrelief conditions. There was on average $4.2 \mathrm{~m}$ more snow and firn in May compared to September 2012 (Figure 4).

Table 2: Changes in mean relative thickness and relative volume of the Triglav Glacier for the 14-hectare area covered by the glacier in 1952 and between two measurements in 2012 (*vertical accuracy for calculating mean relative thickness is $\pm 2 \mathrm{~m}$ or better, except for 1975, for which it may be poorer; ** vertical accuracy is $\pm 0.6 \mathrm{~m}$ or better).

\begin{tabular}{lccc}
\hline Period studied & $\begin{array}{c}\text { Changes in mean } \\
\text { relative thickness }\end{array}$ & $\begin{array}{c}\text { Changes in annual mean } \\
\text { relative thickness }(\mathrm{m} / \text { year })\end{array}$ & $\begin{array}{c}\text { Changes in relative volume } \\
\left({ }^{\prime} 000 \mathrm{~m}^{3}\right)\end{array}$ \\
\hline $1975-1952$ & -10.0 & -0.44 & $-1,407$ \\
$1992-1975$ & -1.5 & -0.09 & -207 \\
$2001-1992$ & -1.3 & -0.14 & -181 \\
$2005-2001$ & -2.6 & -0.64 & -360 \\
$2012-2005$ & -0.4 & -0.05 & -51 \\
$2014-2012$ & 2.9 & 1.46 & 411 \\
\hline September-May 2012 & $-4.2^{* *}$ & & -591 \\
\hline
\end{tabular}

Table 2 presents changes in relative thickness and relative volume between the years studied and the two measurements in 2012. The thickness and volume decrease is especially noticeable in the first two and 


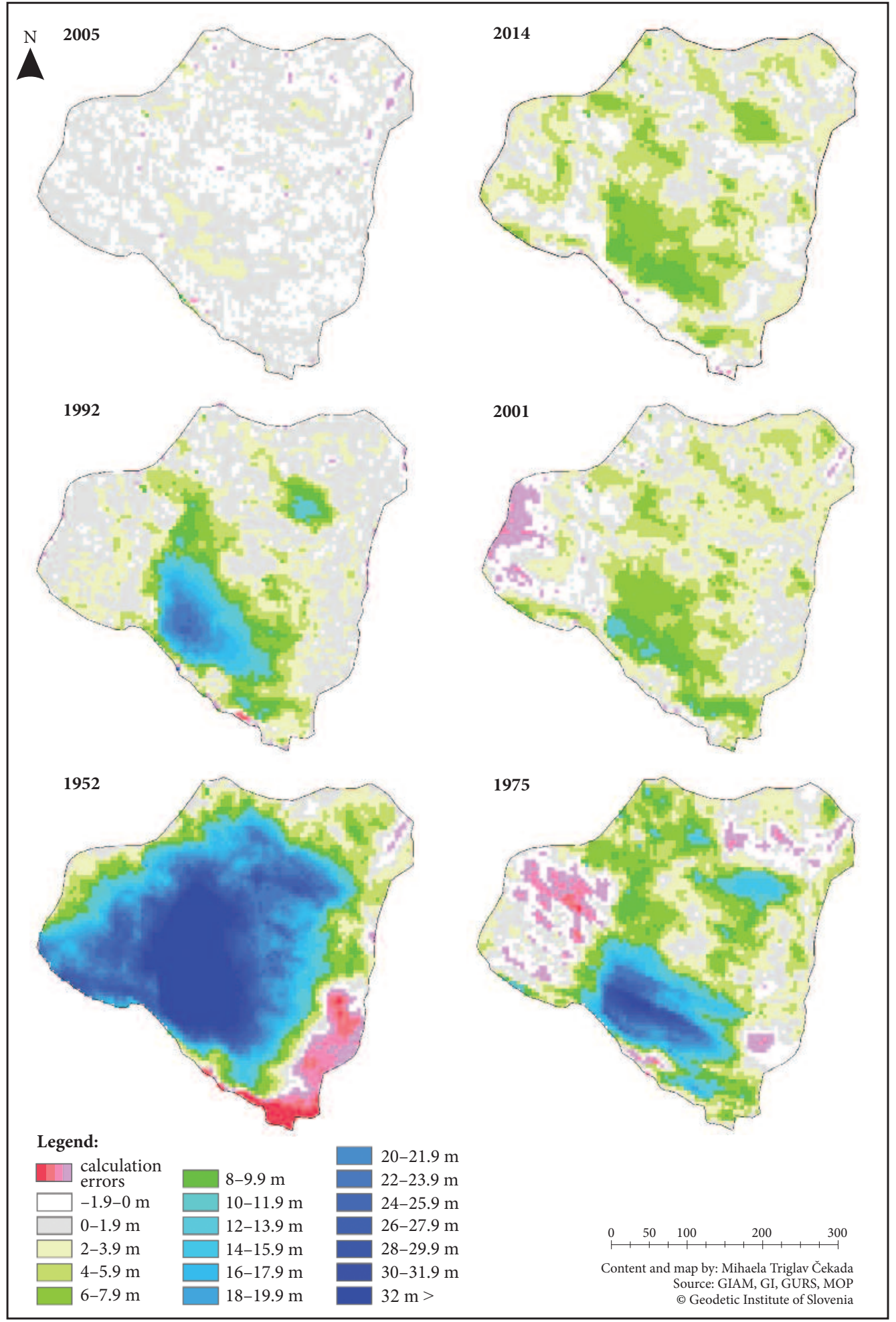


a half decades and at the beginning of the twenty-first century. The change in the first two and a half decades was also noticed by Gabrovec (2008) and Triglav Čekada and Gabrovec (2013; Table 3). Due to favorable years for snow accumulation on the glacier from 2012 to 2014, glacier thickness increased, but as shown in Table 4 the decreasing trend continued in the following years (Figure 6).

Table 3 presents the mean relative thickness and relative volumes relative to 2012 compared to volume calculations previously published in the literature. To be able to directly compare our relative volumes with absolute volumes in the literature, one has to add to the relative volumes a volume of $14,700 \mathrm{~m}^{3}$ (ice and firn) that the glacier amounted to in 2012. The 2012 volume was calculated from the area in $2012(0.6$ hectares; Table 1) and the mean glacier thickness in 2012 (2.45 m; see Section 2.2). These study's volume calculations are to some extent comparable with the volumes given by Gabrovec (2008) based on photogrammetrically derived areas and using the same data sources, although higher. Similar is true compared with values in Triglav Čekada and Gabrovec (2013) except for 1975, where our calculation is much lower, which may be connected to vertical errors for the 1975 calculation (see Section 2.1). The difference may also be attributed to the calculation errors of the source cited because the calculations are based on terrestrial non-metric photography and on an empirical equation. On the other hand, our calculations are much higher compared to the values in Gabrovec (2002b), which were acquired from DTMs based on the topographical maps of the glacier.

Some differences between our calculations and those from the literature may also partly be attributed to large thickness variability on very small glaciers, which cannot be satisfactorily summarized in empirical models. For the same reason, our glacier's mean relative thickness in 1975 is smaller than in 1992 because the former was calculated for a much larger area than the latter. This is not the case if the calculations are

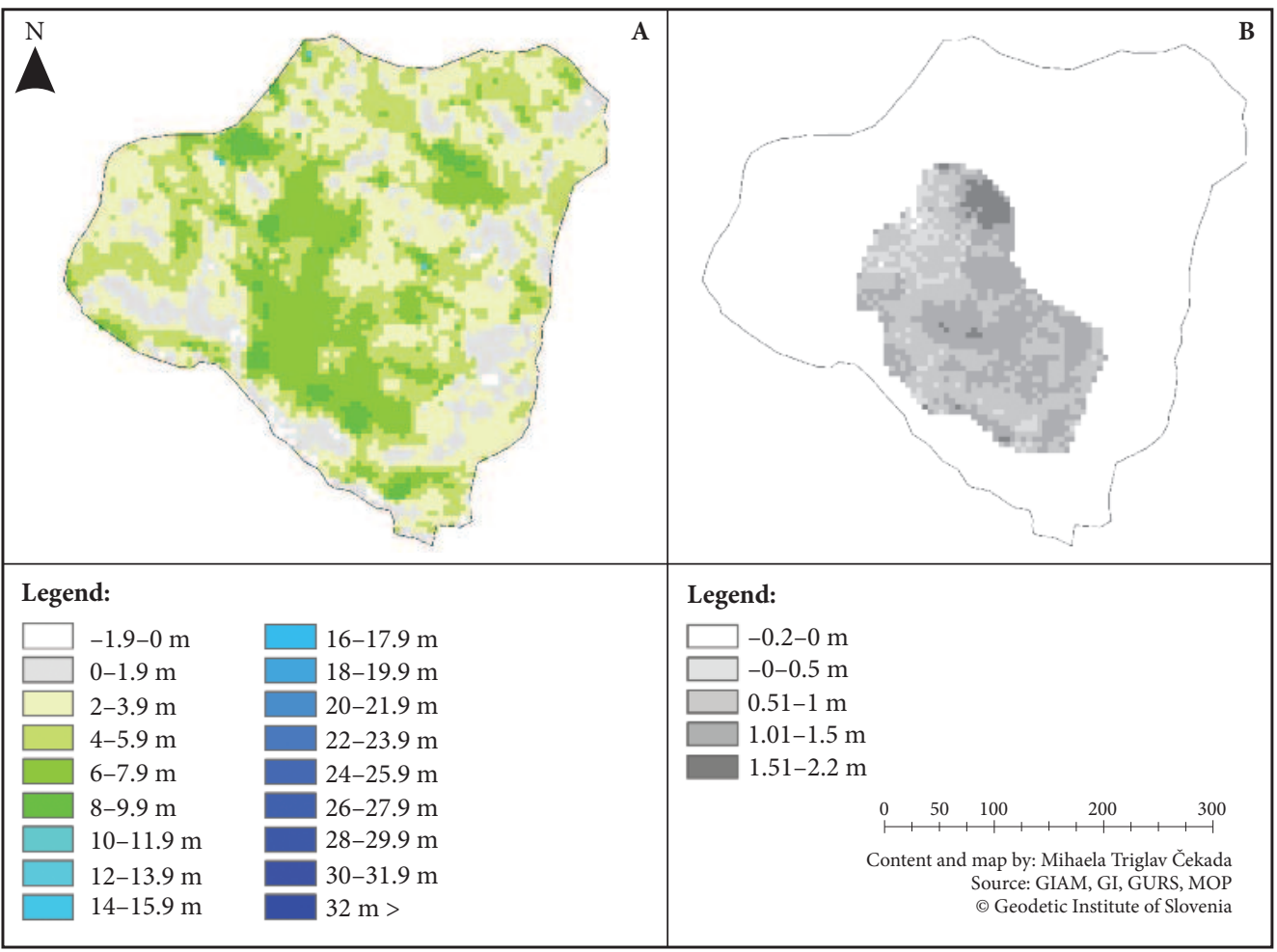

Figure 4: Relative thicknesses of the Triglav Glacier: a) between May and September 2012 and b) between August $8^{\text {th }}$ and $25^{\text {th }}, 2014$ (the former is based on lidar data and the latter on the tachymetric survey). The grid cell size is $5 \times 5 \mathrm{~m}$. The vertical accuracy for calculating mean relative thickness is $\pm 0.6 \mathrm{~m}$ or better. 
made only for the area of 1 hectare that the glacier covered in 2016 (Table 3). Calculations for the area of 1 hectare that the glacier covered in 2016 were primarily made from 1999 to 2016 (Figure 6) because during this period the area of the glacier mainly did not exceed 1 to 2.5 hectares (Table 1 ).

Table 3: Mean relative thickness (*vertical accuracy for calculating mean relative thickness is $\pm 2 \mathrm{~m}$ or better; except for 1975 , for which it may be poorer), relative volume of the Triglav Glacier relative to 2012, and absolute volume. Columns 4, 7, 8, and 9 are summarized from the literature (for area, see Table 1): Gabrovec (2002b), Gabrovec (2008), and Triglav Čekada and Gabrovec (2013; two calculations) (** glacier area in 2016).

\begin{tabular}{|c|c|c|c|c|c|c|c|c|}
\hline $\begin{array}{l}\text { Survey/ } \\
\text { source date }\end{array}$ & $\begin{array}{l}\text { Study area } \\
\text { (hectares) }\end{array}$ & $\begin{array}{l}\text { Mean relative } \\
\text { thickness* } \\
\text { relative to } \\
\text { glacier height } \\
\text { in } 2012(\mathrm{~m})\end{array}$ & $\begin{array}{l}\text { Mean } \\
\text { thickness } \\
\text { by Triglav } \\
\text { Cekada and } \\
\text { Gabrovec } \\
\text { (2013) (m) }\end{array}$ & $\begin{array}{l}\text { Relative } \\
\text { volume } \\
\text { relative } \\
\text { to glacier } \\
\text { height } 2012 \\
\left({ }^{\prime} 000 \mathrm{~m}^{3}\right)\end{array}$ & $\begin{array}{c}\text { Absolute } \\
\text { volume } \\
\left({ }^{\prime} 000 \mathrm{~m}^{3}\right)\end{array}$ & $\begin{array}{c}\text { Volume by } \\
\text { Gabrovec } \\
(2002 \mathrm{~b}) \\
\left({ }^{\prime} 000 \mathrm{~m}^{3}\right)\end{array}$ & $\begin{array}{c}\text { Volume by } \\
\text { Gabrovec } \\
(2008) \\
\left({ }^{\prime} 000 \mathrm{~m}^{3}\right)\end{array}$ & $\begin{array}{l}\text { Volume by } \\
\text { Triglav } \\
\text { Čekada and } \\
\text { Gabrovec } \\
(2013) \\
\left({ }^{\prime} 000 \mathrm{~m}^{3}\right)\end{array}$ \\
\hline October 4, 1952 & $14.0 / 1.0^{* *}$ & $15.7 / 36.8^{* *}$ & - & 2,206 & 2,221 & 1,500 & 2,000 & - \\
\hline October 29, 1975 & $14.0 / 1.0^{* *}$ & $5.7 / 22.3^{* *}$ & 14.5 (1976) & 799 & 814 & - & 700 & $\begin{array}{c}1,408 / \\
2,171.7(1976) \\
\end{array}$ \\
\hline September 8, 1992 & $14.0 / 1.0^{* * *}$ & $9.4 / 17.6^{* *}$ & 9.3 & 406 & 421 & $>135$ & 400 & $356 / 398.5$ \\
\hline September 15, 1999 & $1.0^{* *}$ & $5.4^{* *}$ & 5.7 & 56 & 71 & 35 (2001) & 60 & $60 / 70.5$ \\
\hline August 25, 2005 & $1.0^{* *}$ & $1.7^{* *}$ & 5.7 & 17 & 32 & - & 20 & $5.8 / 27.5$ \\
\hline September 15, 2010 & $1.0^{* *}$ & $4.3^{* *}$ & 4.6 & 43 & 58 & - & - & 27.5 \\
\hline September 24, 2016 & $1.0^{* *}$ & $1.0^{* *}$ & - & 10 & 25 & - & - & - \\
\hline
\end{tabular}

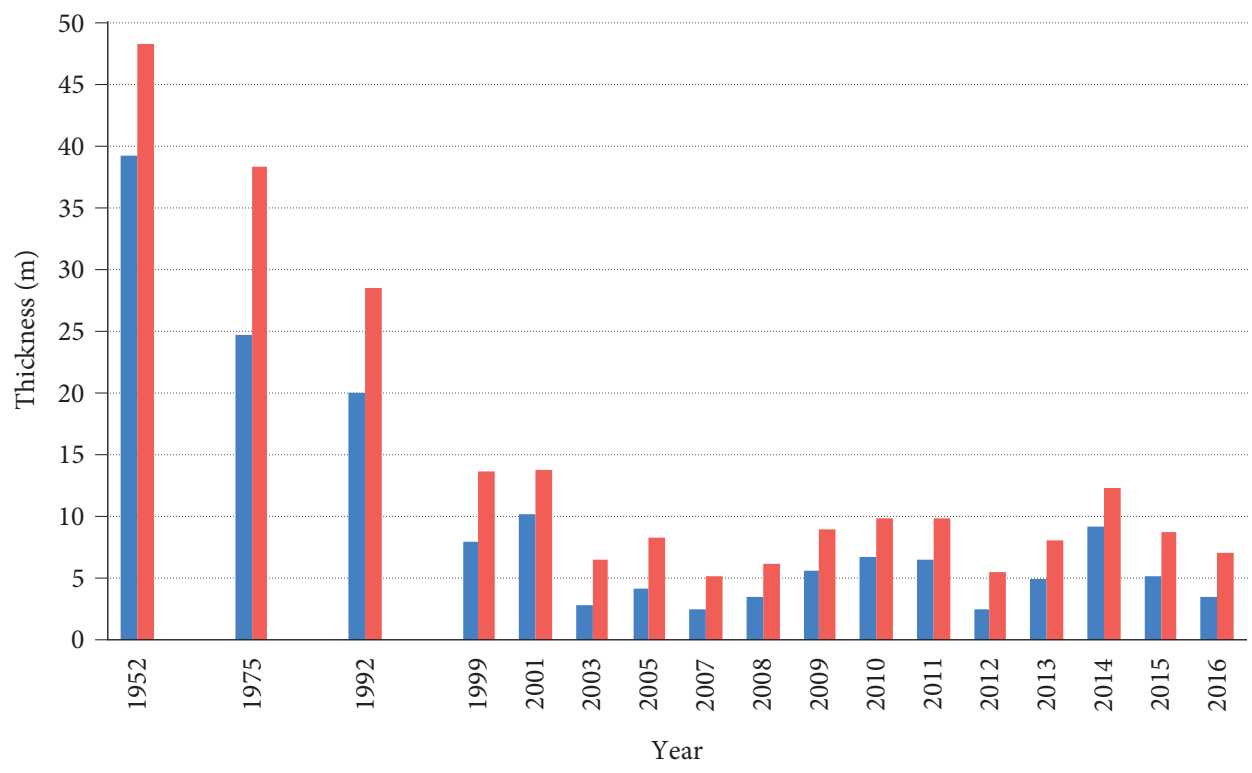

Mean absolute thickness

Maximum absolute thickness

Figure 5: Mean absolute thickness and maximum absolute thickness (including ice, firn, and snow) of the Triglav Glacier from 1952 to 2016. Mean absolute thickness is calculated from relative thickness between the selected year and 2012 for an area of 1 hectare and taking into the account GPRS 2013 mean absolute thickness. Maximum absolute thickness was calculated for the location of maximum GPRS thickness in 2013. 
Our volumes are also much higher compared to the volumes calculated from GPRS measurements. According to the GPRS measurements, in 2000 the glacier volume was about $35,000 \mathrm{~m}^{3}$ (Verbič and Gabrovec 2002) and in 2013 about 7,400 $\mathrm{m}^{3}$ (Del Gobbo et al. 2016). The differences may partly be attributed to the errors connected with our modeling, but also with the fact that our glacier volumes contain a combined volume of ice, firn, and snow, and not only ice volumes, as is the case with the GPRS measurements.

Figure 5 shows that during the period studied the glacier's maximum absolute thickness decreased from $48.3 \mathrm{~m}$ (in 1952) to $5.2 \mathrm{~m}$ (in 2007), and its mean absolute thickness from $39.2 \mathrm{~m}$ (in 1952) to $2.45 \mathrm{~m}$ (in 2012). Similar thinning was reported by Gabrovec (2002a, 2000b), who calculated a thickness decrease up to $35 \mathrm{~m}$ for a shorter period (1952-1999/2001).

The lowest mean absolute thicknesses of the glacier were calculated for 2003, 2007, 2008, 2012, and 2016. In these years, the mean absolute thickness did not exceed $3.5 \mathrm{~m}$. Even in these years, the glacial ice was still preserved under a layer of firn because the mean thickness of ice does not exceed $1.95 \mathrm{~m}$, as mentioned above in the description of the 2013 GPRS measurement. In addition, the maximum absolute thicknesses in these years, measured for the same location where the maximum thickness was measured by GPRS in 2013, did not exceed $6.5 \mathrm{~m}$.

Table 3 compares our mean relative thicknesses to the glacier mean thicknesses in Triglav Čekada and Gabrovec (2013). To be able to directly compare our relative thicknesses with those from the literature, it is necessary to add a mean glacier thickness from 2012 (2.45 m; see Section 2.2) to the relative thicknesses. For 1975 and 2005, our calculations of the mean glacier thickness are lower, and for 1992, 1999, and 2010 they are higher than in Triglav Čekada and Gabrovec (2013). Here the differences can also be attributed to the different methods and errors connected with the sources used.

Figure 6 shows the differences in the relative glacier thickness (together for ice, firn, and snow) from 1999 to 2016 relative to 2012. In the favorable years for the glacier $(1999,2001,2010,2011$, and 2014), surplus masses accumulated at the southern (i.e., the upper, highest, and steepest) part of the glacier alongside Mount Triglav's rock wall. In 2003, 2007, and 2008, the thickness of the glacier was almost the same as in 2012. The mass deficit is seen in the northern (i.e., the lower) part of the glacier. During six years between 2009 and 2014, excluding 2012, the glacier thickness increased. In 2015 and 2016 the glacier thinned again (Table 4).

Table 4: Changes in mean relative thickness ( ${ }^{*}$ vertical accuracy for calculating mean relative thickness is $\pm 2 \mathrm{~m}$ or better; except for 1975, for which it may be poorer) and annual mean relative thickness as well as changes in relative volume for the area of 1 hectare that the Triglav Glacier covered in 2016.

\begin{tabular}{|c|c|c|c|}
\hline Time difference & $\begin{array}{l}\text { Changes in mean } \\
\text { relative thickness* }(m)\end{array}$ & $\begin{array}{l}\text { Changes in annual mean } \\
\text { relative thickness (m/year) }\end{array}$ & $\begin{array}{l}\text { Changes in relative } \\
\text { volume ('000 m³) }\end{array}$ \\
\hline $1975-1952$ & -14.5 & -0.6 & -149 \\
\hline 1992-1975 & -4.7 & -0.3 & -49 \\
\hline 1999-1992 & -12.1 & -1.7 & -124 \\
\hline 2001-1999 & 2.3 & 1.2 & 23 \\
\hline $2003-2001$ & -7.4 & -3.7 & -76 \\
\hline $2005-2003$ & 1.4 & 0.7 & 15 \\
\hline $2007-2005$ & -1.7 & -0.9 & -17 \\
\hline 2008-2007 & 1.0 & 1.0 & 10 \\
\hline 2009-2008 & 2.1 & 2.1 & 21 \\
\hline 2010-2009 & 1.2 & 1.2 & 12 \\
\hline $2011-2010$ & -0.3 & -0.3 & -3 \\
\hline $2012-2011$ & -4.0 & -4.0 & -41 \\
\hline $2013-2012$ & 2.6 & 2.6 & 27 \\
\hline 2014-2013 & 4.1 & 4.1 & 42 \\
\hline $2015-2014$ & -5.0 & -5.0 & -51 \\
\hline $2016-2015$ & -1.8 & -1.8 & -17 \\
\hline
\end{tabular}


Acta geographica Slovenica, 60-2, 2020

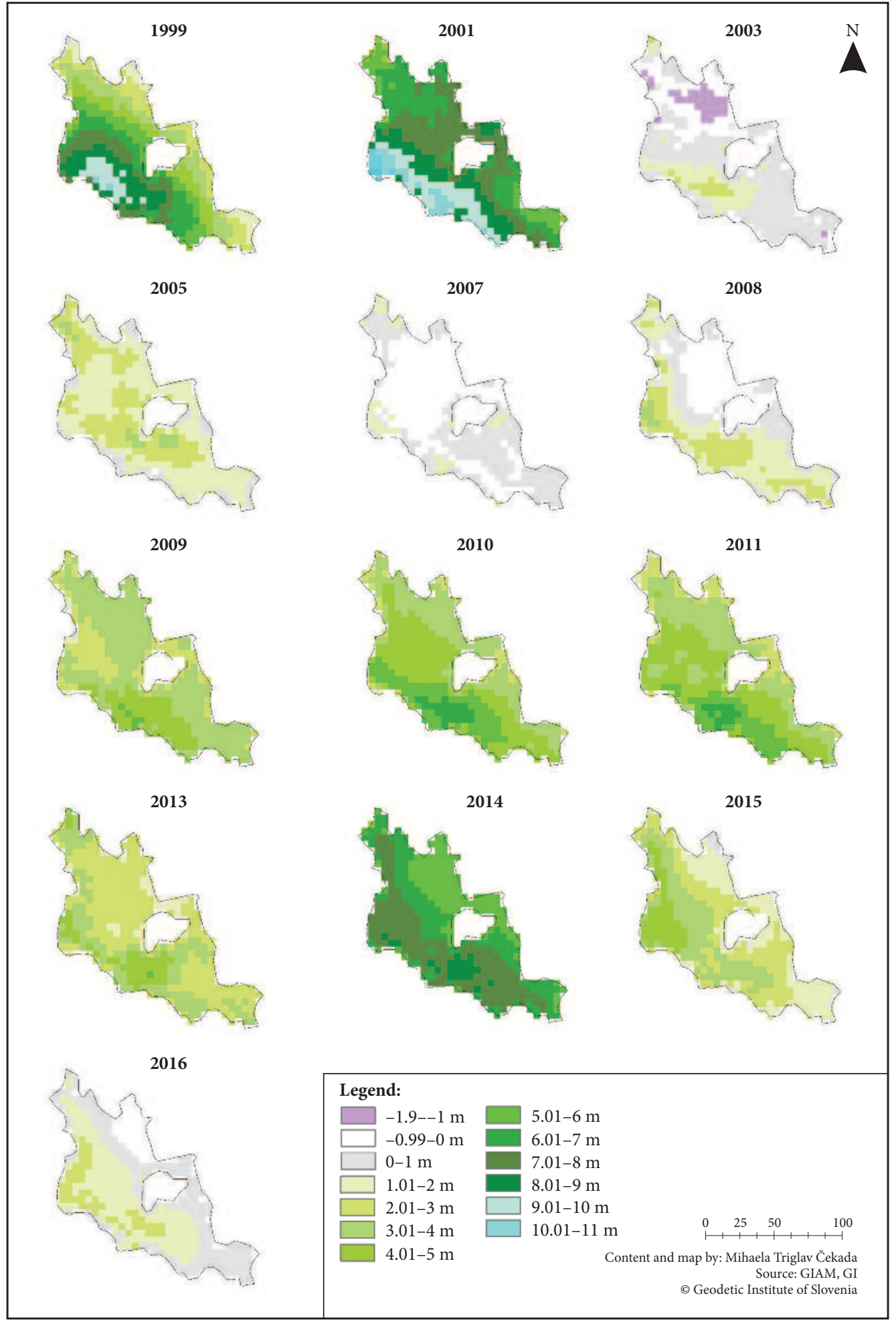


Mihaela Triglav Čekada, Matija Zorn, Thickness and geodetic mass balance changes for the Triglav Glacier (southeastern Alps)...

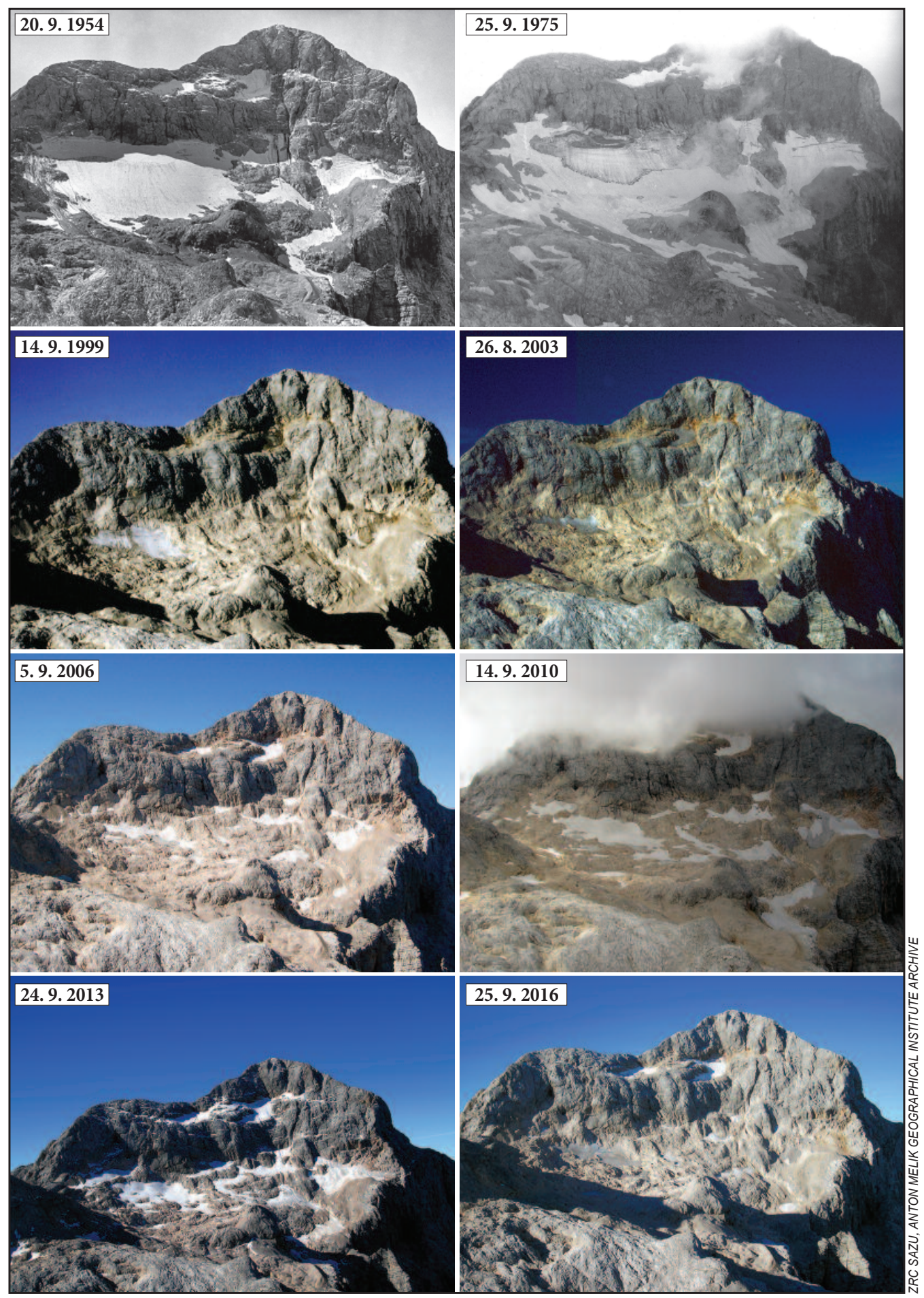

Figure 7: The Triglav Glacier in selected years from 1954 to 2016. 
Table 4 presents the inter-annual mean relative thicknesses and relative volumes of the Triglav Glacier, which were calculated for the area of 1 hectare covered by the glacier in 2016. In this area, the glacier thinned on average by $0.6 \mathrm{~m}$ per year between 1952 and 2016. The most significant reduction of relative thickness occurred from 1992 to 1999, when the glacier thinned on average by $1.7 \mathrm{~m}$ per year. Similar is reported by Gabrovec (2002a), who stated that the glacier thinned by 1 to $2 \mathrm{~m}$ annually in the late 1980 s, and by $2 \mathrm{~m}$ at the beginning of the 1990 s.

From 1999 to 2016, it thinned on average by $0.3 \mathrm{~m}$ per year, between 1999 and 2009 by $0.2 \mathrm{~m}$ per year, and between 2009 and 2016 by $0.5 \mathrm{~m}$ per year. The last can be attributed to accelerated thinning of the glacier in 2015 and 2016, when it thinned by $5 \mathrm{~m}$ in the glacier year 2014-2015 and $1.8 \mathrm{~m}$ in the glacier year 2015-2016. Figure 5 shows that all the surplus that accumulated on the glacier in 2013 and 2014 melted in 2015 and 2016.

For the Slovenian Alps, considerable changes in glacier thickness in the last half century are also reported for the Skuta Glacier (Triglav Čekada et al. 2020).

\subsection{Mass balance}

The mean specific mass balance between 1952 and 2007 was negative, between 2007 and 2010 it was positive, and it has fluctuated significantly in the last decade (Figure 8). The fluctuations can be explained by high accumulation of snow that fell on the glacier in favorable (i.e., snow-rich) years, and the total melting of this snow in the next (for the glacier, unfavorable) year. The annual mean specific mass balances for 1952 to 2016 are shown in Figure 9, where cumulative mass balances are also given.

The average annual specific mass balance for the entire period studied (1952-2016) was $-0.45 \mathrm{~m}$ w.e. $\mathrm{a}^{-1}$. This value is similar to the long-term average specific mass balance of $-0.39 \mathrm{~m}$ w.e. $\mathrm{a}^{-1}$ for all Swiss glaciers

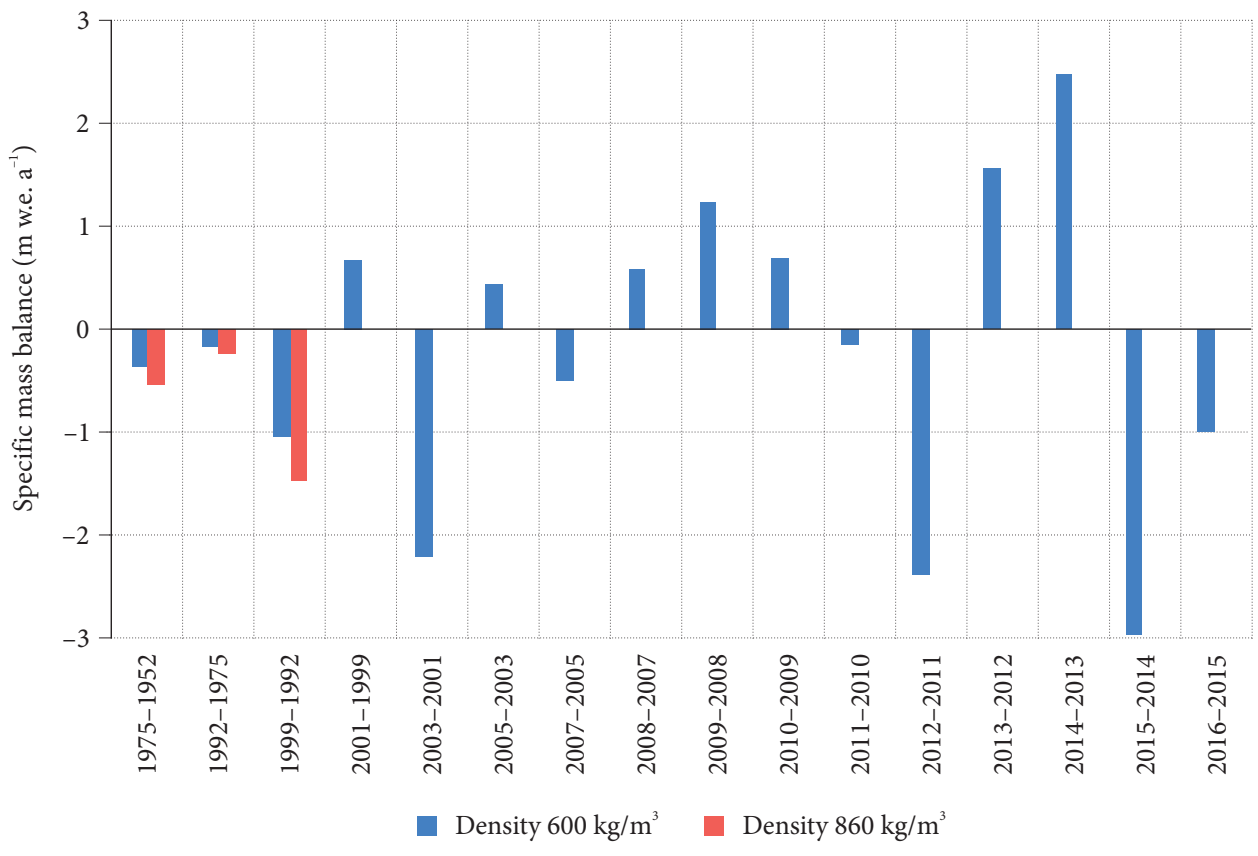

Figure 8: Mean specific mass balance for the area of 1 hectare that the Triglav Glacier covered in 2016. 


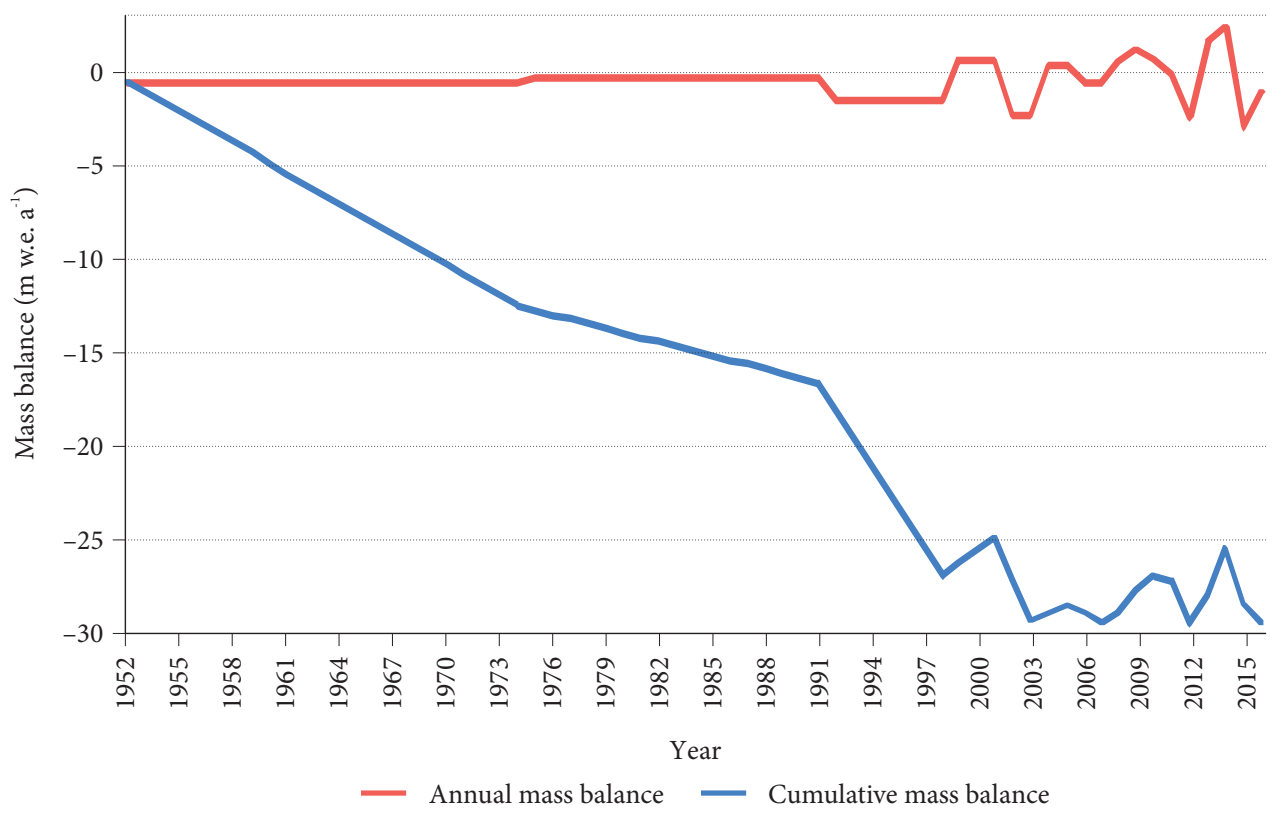

Figure 9: Annual specific mass balance and cumulative mass balance for the area of 1 hectare that the Triglav Glacier covered in 2016 (for uniform density $\left.600 \mathrm{~kg} / \mathrm{m}^{3}\right)$.

from 1969 to 2006 (Fischer, Huss, and Hoelzle 2015) and $-0.62 \mathrm{~m}$ w.e. $\mathrm{a}^{-1}$ for the French Sarennes Glacier from 1952 to 2003 (Thibert et al. 2008).

After the turn of the century, the average annual mean specific mass balance on the Triglav Glacier was $-0.07 \mathrm{~m}$ w.e. $\mathrm{a}^{-1}$ from 1999 to $2009,-0.26 \mathrm{~m}$ w.e. $\mathrm{a}^{-1}$ from 2010 to 2016, and $-0.14 \mathrm{~m}$ w.e. $\mathrm{a}^{-1}$ from 1999 to 2016. Comparing these data with the data for other Alpine glaciers from 1999 to 2009, it can be seen that the trend of annual specific mass balances for other European Alpine glaciers was predominantly negative and higher than that of the Triglav Glacier. Huss (2012) states for entire European Alps an annual specific mass balance of $-0.99 \mathrm{~m}$ w.e. $\mathrm{a}^{-1}$ and Hagg et al. (2012) give specific mass balance values between $-0.9 \mathrm{~m}$ w.e. $\mathrm{a}^{-1}$ and $-0.5 \mathrm{~m}$ w.e. $\mathrm{a}^{-1}$ for the group of five small glaciers in the Bavarian Alps. Zemp et al. (2015) give an average geodetically derived mass balance of $-0.70 \mathrm{~m}$ w.e. $\mathrm{a}^{-1}$ for more than 100 glaciers in the central Alps and a glaciological mass balance of $-1.03 \mathrm{~m} \mathrm{w} \cdot \mathrm{e}^{-1} \mathrm{a}^{-1}$ for a smaller number of glaciers. They also report a global geodetic mass balance average of $-0.8 \mathrm{~m}$ w.e. $\mathrm{a}^{-1}$ for the same period. In summary, in the Alps, the specific mass balance was approximately $-1.0 \mathrm{~m}$ w.e. $\mathrm{a}^{-1}$ in the first decade of the twenty-first century.

From 2010 to 2015, Huss, Dhulst, and Bauder (2015) give an annual specific mass balance of about $-1.0 \mathrm{~m}$ w.e. $\mathrm{a}^{-1}$ for the Austrian and Italian Alps, and $-0.8 \mathrm{~m}$ w.e. $\mathrm{a}^{-1}$ for the Swiss Alps. Carturan et al. (2016) give an annual specific mass balance between -1.79 and $-0.76 \mathrm{~m}$ w.e. $\mathrm{a}^{-1}$ for selected Italian glaciers from 2004 to 2013. In 2013, the specific mass balance values began to increase, similar to the Triglav Glacier in 2013 and 2014.

The values of the Triglav Glacier differ to some extent from the cited cases, which can be partly attributed to the fact that those studies mentioned mainly included larger glaciers. Abermann et al. (2009) already determined that the thickness of very small glaciers decreases more slowly in comparison to larger glaciers. The lower values of the annual specific mass balances obtained for the Triglav Glacier may also be related to favorable micro-relief conditions (Kuhn 1995) that help preserve it. Other studies of changes in mass balance for very small glaciers also show a significant impact of local micro-relief on the mass balance 
in addition to the meteorological parameters (Kuhn 1995; Schöner and Böhm 2007; DeBeer and Sharp 2009; Shahgedanova et al. 2012; Colucci and Guglielmin 2015; Carturan et al. 2016; Huss and Fischer 2016).

\section{Conclusion}

The thickness and volumetric changes for the Triglav Glacier, as well as its mass balance, were determined for over six decades. During this period its maximum thickness decreased from $48.3 \mathrm{~m}$ (in 1952) to $5.2 \mathrm{~m}$ (in 2007) and its mean thickness from $39.2 \mathrm{~m}$ (in 1952) to $2.45 \mathrm{~m}$ (in 2012).

The mean annual specific mass balance was $-0.45 \mathrm{~m}$ w.e. $\mathrm{a}^{-1}$ in the entire period studied (1952-2016), $-0.07 \mathrm{~m}$ w.e. $\mathrm{a}^{-1}$ from 1999 to 2009 , and $-0.26 \mathrm{~m}$ w.e. $\mathrm{a}^{-1}$ from 2010 to 2016 . The values obtained are lower if compared to the mass balances of other Alpine glaciers.

ACKNOWLEDGEMENTS: The authors acknowledge financial support from the Slovenian Research Agency research core funding Geography of Slovenia (P6-0101) and the research project funding Predictive Analytics Based on Location-Associated Context Enrichment (J2-8176). The authors are grateful to everyone that contributed to the measurements of the Triglav Glacier because this research would not have been possible without them.

\section{References}

Abermann, J., Lambrecht, A., Fischer, A., Kuhn, M. 2009: Quantifying changes and trends in glacier area and volume in the Austrian Otztal Alps (1969-1997-2006). The Cryosphere 3-2. DOI: https://doi.org/ 10.5194/tc-3-205-2009

Benn, D. I., Evans, D. J. A. 2010: Glaciers and glaciation. London, New York.

Brown, J., Harper, J., Humphrey, N. 2010: Cirque glacier sensitivity to 21st century warming: Sperry Glacier, Rocky Mountains, USA. Global and Planetary Change 74-2. DOI: https://doi.org/10.1016/ j.gloplacha.2010.09.001

Carturan, L., Baroni, C., Brunetti, M., Carton, A., Fontana, G. D., Salvatore, M. C., Zanoner, T., Zuecco, G. 2016: Analysis of the mass balance time series of glaciers in the Italian Alps. The Cryosphere 10-2. DOI: https://doi.org/10.5194/tc-10-695-2016

Colucci, R. R., Guglielmin, M. 2015: Precipitation-temperature changes and evolution of a small glacier in the southeastern European Alps during the last 90 years. International Journal of Climatology 35-10. DOI: https://doi.org/10.1002/joc.4172

DeBeer, C. M., Sharp, M. J. 2009: Topographic influences on recent changes of very small glaciers in the Monashee Mountains, British Columbia, Canada. Journal of Glaciology 55-192. DOI: https://doi.org/ $10.3189 / 002214309789470851$

Del Gobbo, C., Colucci, R. R., Forte, E., Triglav Čekada, M., Zorn, M. 2016: The Triglav glacier (SouthEastern Alps, Slovenia): Volume estimation, internal characterization and 2000-2013 temporal evolution by means of ground penetrating radar measurements. Pure and Applied Geophysics 173. DOI: https://doi.org/10.1007/s00024-016-1348-2

Fischer, A. 2011: Comparison of direct and geodetic mass balances on a multi-annual time scale. The Cryosphere 5-1. DOI: https://doi.org/10.5194/tc-5-107-2011

Fischer, M., Huss, M., Hoelzle, M. 2015: Surface elevation and mass changes of all Swiss glaciers 1980-2010. The Cryosphere 9-2. DOI: https://doi.org/10.5194/tc-9-525-2015

Gabrovec, M. 2002a: The Triglav Glacier. High-mountain lakes in the Eastern part of the Julian Alps. Ljubljana.

Gabrovec, M. 2002b: Spremembe prostornine Triglavskega ledenika. Dela 18. DOI: https://doi.org/10.4312/ dela.18.133-141

Gabrovec, M. 2008: Il ghiacciaio del Triglav (Slovenia) - The Triglav Glacier. Ghiacciai montani e cambiamenti climatici nell' ultimo secolo - Mountain Glaciers and Climate Changes in the Last Century. Milano.

Gabrovec, M., Hrvatin, M., Komac, B., Ortar, J., Pavšek, M., Topole, M., Triglav Čekada, M., Zorn, M. 2014: Triglavski ledenik. Geografija Slovenije 30. Ljubljana. DOI: https://doi.org/10.3986/9789610503644 
Gabrovec, M., Komac, B., Pavšek, M., Triglav Čekada, M. 2009: Triglavski ledenik kot pokazatelj podnebnih sprememb. Končno poročilo, Geografski inštitut Antona Melika ZRC SAZU. Ljubljana.

Gabrovec, M., Ortar, J., Pavšek, M., Zorn, M., Triglav Čekada, M. 2013: The Triglav glacier between the years 1999 and 2012. Acta geographica Slovenica 53-2. DOI: https://doi.org/10.3986/AGS53202

Hagg, W., Mayer, C., Mayr, E., Heilig, A. 2012: Climate and glacier fluctuations in the Bavarian Alps in the past 120 years. Erdkunde 66-2. DOI: https://doi.org/10.3112/erdkunde.2012.02.03

Hughes, P. D. 2018: Little Ice Age glaciers and climate in the Mediterranean mountains: a new analysis. Cuadernos de Investigación Geográfica 44-1. DOI: https://doi.org/10.18172/cig.3362

Huss, M. 2012: Extrapolating glacier mass balance to the mountain-range scale: The European Alps 1900-2100. The Cryosphere 6-4. DOI: https://doi.org/10.5194/tc-6-713-2012

Huss, M. 2013: Density assumptions for converting geodetic glacier volume change to mass change. The Cryosphere 7-3. DOI: https://doi.org/10.5194/tc-7-877-2013

Huss, M., Dhulst, L., Bauder, A. 2015: New long-term mass-balance series for the Swiss Alps. Journal of Glaciology 61-227. DOI: https://doi.org/10.3189/2015JoG15J015

Huss, M., Fischer, M. 2016: Sensitivity of very small glaciers in the Swiss Alps to future climate change. Frontiers in Earth Science 4. DOI: https://doi.org/10.3389/feart.2016.00034

Kuhn, M. 1995: The mass balance of very small glaciers. Zeitschrift für Gletscherkunde und Glazialgeologie 31, 1-2.

Kumar, R. 2011: Glacieret. Encyclopedia of Snow, Ice and Glaciers. Dordrecht. DOI: https://doi.org/10.1007/ 978-90-481-2642-2_203

Lipar, M., Martín-Pérez, A., Tičar, J., Pavšek, M., Gabrovec, M., Hrvatin, M., Komac, B., Zorn, M., Zupan Hajna, N., Zhao, J.-X., Drysdale, R. N., Ferk, M. 2021; Subglacial carbonate deposits as a potential proxy for a glacier's former presence. The Cryosphere 15. DOI: https://doi.org/10.5194/tc-15-17-2021

Schöner, W., Böhm, R. 2007: a statistical mass-balance model for reconstruction of LIA ice mass for glaciers in the European Alps. Annals of Glaciology 46. DOI: https://doi.org/10.3189/172756407782871639

Schwerzmann, A., Funk, M., Blatter, H., Lüthi, M., Schwikowski, M., Palmer, A. 2006: A method to reconstruct past accumulation rates in alpine firn regions: a study on Fiescherhorn, Swiss Alps. Journal of Geophysical Research 111-F1. DOI: https://doi.org/10.1029/2005JF000283

Shahgedanova, M., Nosenko, G., Bushueva, I., Ivanov, M. 2012: Changes in area and geodetic mass balance of small glaciers, Polar Urals, Russia, 1950-2008. Journal of Glaciology 58-211. DOI: https://doi.org/ 10.3189/2012JoG11J233

Slater, T., Lawrence, I. R., Otosaka, I. N., Shepherd, A., Gourmelen, N., Jakob, L., Tepes, P., Gilbert, L. 2020: Review Article: Earth's ice imbalance. The Cryosphere Discussions. DOI: https://doi.org/10.5194/ tc-2020-232

Thibert, E., Blanc, R., Vincent, C., Eckert, N. 2008: Glaciological and volumetric mass-balance measurements: error analysis over 51 years for Glacier de Serennes, French Alps. Journal of Glaciology 54-186. DOI: https://doi.org/10.3189/002214308785837093

Triglav Čekada, M. 2018: Ledeniki na kartah vojaške izmere avstro-ogrske monarhije. Raziskave s področja geodezije in geofizike 2017. Ljubljana.

Triglav Čekada, M., Barbo, P., Pavšek, M., Zorn, M. 2020: Changes in the Skuta Glacier (southeastern Alps) assessed using non-metric images. Acta geographica Slovenica 60-2. DOI: https://doi.org/10.3986/ AGS.7674

Triglav Čekada, M., Bric, V., Klanjšček, M., Barborič, B., Pavšek, M. 2013: Zračno lasersko skeniranje zasneženega površja. Raziskave s področja geodezije in geofizike 2012. Ljubljana.

Triglav Čekada, M., Crosilla, F., Kosmatin Fras, M. 2009: A simplified analytical model for a-priori lidar point positioning error estimation and a review of lidar error sources. Photogrammetric Engineering and Remote Sensing 75-12. DOI: https://doi.org/10.14358/PERS.75.12.1425

Triglav Čekada, M., Crosilla, F., Kosmatin Fras, M. 2010: Theoretical lidar point density for topographic mapping in the largest scales. Geodetski vestnik 54-3. DOI: https://doi.org/10.15292/geodetski-vestnik.2010.03.403-416

Triglav Čekada, M., Gabrovec, M. 2008: Zgodovina geodetskih meritev na Triglavskem ledeniku. Geodetski vestnik 52-3.

Triglav Čekada, M., Gabrovec, M. 2013: Documentation of Triglav glacier, Slovenia, using non-metric panoramic images. Annals of Glaciology 54-62. DOI: https://doi.org/10.3189/2013AoG62A095 
Triglav Čekada, M., Zorn, M., Colucci, R. R. 2014: Changes in the area of the Canin (Italy) and Triglav glaciers (Slovenia) since 1893 based on archive images and aerial laser scanning. Geodetski vestnik 58-2. DOI: https://doi.org/10.15292/geodetski-vestnik.2014.02.274-313

Verbič, T., Gabrovec, M. 2002: Georadarske meritve na Triglavskem ledeniku. Geografski vestnik 74-1. Vrhovec, T., Velkavrh, A. 2001: Največja debelina snežne odeje na Kredarici. Geografski vestnik 73-2. Zängl, W., Hamberger, S. 2004: Gletscher in Treibhaus. Steinfurt.

Zemp, M., Frey, H., Gärtner-Roer, I., Nussbaumer, S., Hoelzle, M., Paul, F., Haeberli, W., Denzinger, F., Ahlstrøm, A. P., Anderson, B., Bajracharya, S., Baroni, C., Braun, L. N., Cáceres, B. E., Casassa, G., Cobos, G., Dávila, L. R., Delgado Granados, H., Demuth, M. N., Espizua, L., Fischer, A., Fujita, K., Gadek, B., Ghazanfar, A., Hagen, J. O., Holmlund, P., Karimi, N., Li, Z., Pelto, M., Pitte, P., Popovnin, V. V., Portocarrero, C. A., Prinz, R., Sangewar, C. V., Severskiy, I., Sigurđsson, O., Soruco, A., Usubaliev, R., Vincent, C. 2015: Historically unprecedented global glacier decline in the early 21st century. Journal of Glaciology 61-228. DOI: https://doi.org/10.3189/2015JoG15J017

Zemp, M., Jansson, P., Holmlund, P., Gärtner-Roer, J., Koblet, T., Three, P., Haeberli, W. 2010: Reanalysis of multi-temporal aerial images of Storglaciären, Sweden (1959-99) - Part 2: Comparison of glaciological and volumetric mass balance. The Cryosphere 4-3. DOI: https://doi.org/10.5194/tc-4-345-2010 